\title{
Treatment of amphibians infected with chytrid fungus: learning from failed trials with itraconazole, antimicrobial peptides, bacteria, and heat therapy
}

\author{
Douglas C. Woodhams ${ }^{1, *}$, Corina C. Geiger ${ }^{1}$, Laura K. Reinert ${ }^{2}$, \\ Louise A. Rollins-Smith ${ }^{2,3}$, Brianna Lam ${ }^{4}$, Reid N. Harris ${ }^{4}$, Cheryl J. Briggs ${ }^{5}$, \\ Vance T. Vredenburg ${ }^{6}$, Jamie Voyles ${ }^{7}$ \\ ${ }^{1}$ Ecology Group, Institute of Evolutionary Biology and Environmental Studies, University of Zurich, Winterthurerstrasse 190, \\ 8057 Zurich, Switzerland \\ ${ }^{2}$ Department of Pathology, Microbiology and Immunology, and ${ }^{3}$ Department of Pediatrics, Vanderbilt University Medical Center, \\ Vanderbilt University, Nashville, Tennessee 37232, USA \\ ${ }^{4}$ Department of Biology, James Madison University, Harrisonburg, Virginia 22807, USA \\ ${ }^{5}$ Department of Ecology, Evolution, and Marine Biology, University of California, Santa Barbara, California 93106-9610, USA \\ ${ }^{6}$ Department of Biology, San Francisco State University, San Francisco, California 94132-1722, USA \\ ${ }^{7}$ Department of Biological Sciences, University of Idaho, Moscow, Idaho 83844, USA
}

\begin{abstract}
Amphibian conservation goals depend on effective disease-treatment protocols. Desirable protocols are species, life stage, and context specific, but currently few treatment options exist for amphibians infected with the chytrid fungus Batrachochytrium dendrobatidis $(B d)$. Treatment options, at present, include antifungal drugs and heat therapy, but risks of toxicity and sideeffects make these options untenable in some cases. Here, we report on the comparison of several novel treatments with a more generally accepted antifungal treatment in experimental scientific trials to treat $B d$-infected frogs including Alytes obstetricans tadpoles and metamorphs, Bufo bufo and Limnodynastes peronii metamorphs, and Lithobates pipiens and Rana muscosa adults. The experimental treatments included commercial antifungal products (itraconazole, mandipropamid, steriplantN, and PIP Pond Plus), antimicrobial skin peptides from the $B d$-resistant Pelophylax esculentus, microbial treatments (Pedobacter cryoconitis), and heat therapy $\left(35^{\circ} \mathrm{C}\right.$ for $\left.24 \mathrm{~h}\right)$. None of the new experimental treatments were considered successful in terms of improving survival; however, these results may advance future research by indicating the limits and potential of the various protocols. Caution in the use of itraconazole is warranted because of observed toxicity in metamorphic and adult frogs, even at low concentrations. Results suggest that rather than focusing on a single cure-all, diverse lines of research may provide multiple options for treating $B d$ infection in amphibians. Learning from 'failed treatments' is essential for the timely achievement of conservation goals and one of the primary aims for a publicly accessible treatment database under development.
\end{abstract}

KEY WORDS: Alytes obstetricans - Batrachochytrium dendrobatidis $\cdot$ Biotherapy $\cdot$ Bufo bufo Chytridiomycosis $\cdot$ Disease control $\cdot$ Lithobates pipiens $\cdot$ Probiotic $\cdot$ Rana muscosa Resale or republication not permitted without written consent of the publisher

\section{INTRODUCTION}

Amphibians are more threatened than any other vertebrate taxon (Stuart et al. 2004, Hoffmann et al. 2010). One significant factor contributing to popula- tion declines is an emerging infectious disease called chytridiomycosis caused by the fungus Batrachochytrium dendrobatidis (Bd) (Berger et al. 1998, Daszak et al. 2000, Skerratt et al. 2007). Chytridiomycosis causes death to amphibians both in the labora- 
tory (Parker et al. 2002, Tobler \& Schmidt 2010) and in natural habitats (Berger et al. 1998, Bosch et al. 2001, Lips et al. 2006, Pounds et al. 2006). The disease is associated with mass mortality events, population declines (Vredenburg et al. 2010), the loss of amphibian biodiversity (Daszak et al. 2003, Lips et al. 2006, Smith et al. 2009), and subsequent ecosystem changes (Whiles et al. 2006). Chytridiomycosis was characterized in the IUCN Amphibian Conservation Action Plan as the worst infectious disease ever recorded among vertebrates in terms of the number of species impacted, and its propensity to drive them to extinction' (Gascon et al. 2007, p. 59). Hence, it is of particular importance to develop effective methods to mitigate $B d$ (Woodhams et al. 2011) and also to cure infected amphibians (Mendelson et al. 2006).

The urgent development of antifungal treatment protocols has resulted in several reports (Nichols et al. 2000, Berger et al. 2010, Bowerman et al. 2010, Pessier \& Mendelson 2010, Martel et al. 2011, Tamukai et al. 2011). Successful trials have been documented in peer-reviewed journals. These reports include treatment with elevated temperature (Woodhams et al. 2003, Chatfield \& Richards-Zawacki 2011, Geiger et al. 2011), treatment with salt (White 2006), and also treatments with different antifungals (Hadfield \& Whitaker 2005, Garner et al. 2009a, Bowerman et al. 2010, Martel et al. 2011). Unfortunately, information about unsuccessful trials is scarce (Berger et al. 2009). Anecdotal reports of both successful and unsuccessful treatments used in the pet trade, zoos, and for captive assurance colonies are becoming more numerous. These unpublished reports may help to guide future clinical studies. To be efficient in developing successful mitigation methods against $B d$, intuitive yet unsuccessful trials should not be needlessly repeated. Thus, documentation of failed trials is important for future research planning.

Here, we report on 5 experiments that were considered unsuccessful treatments in terms of improving amphibian survival, and we also outline what can be learned from these unsuccessful treatment attempts. First, we examine treatments of newly metamorphosed common toads Bufo bufo. This species is common, yet susceptible to chytridiomycosis (Bosch \& Rincón 2008, Fisher et al. 2009, Garner et al. 2009b, 2011) and, therefore, a good model species for development of treatment protocols. Since the species does not appear to produce conventional cationic antimicrobial skin peptides (Roseghini et al. 1989), we chose to examine the effects of adding anti- $B d$ skin peptides from a disease-resistant species. If the added antimicrobial peptides reduce the pathogen load, the adaptive immune system may be better able to clear infections. Second, adult mountain yellow-legged frogs Rana muscosa were treated with either itraconazole or the anti-Bd bacterium Pedobacter cryoconitis. Third, itraconazole and heat treatments were tested on infected adult northern leopard frogs Lithobates pipiens. Successful treatment of this infection-tolerant reservoir host (Woodhams et al. 2008) could be implemented by commercial suppliers to reduce the spread of $B d$. Metamorphosing striped marsh frogs Limnodynastes peronii and midwife toads Alytes obstetricans show a typical pattern of chytridiomycosis development at metamorphosis (Marantelli et al. 2004, Tobler \& Schmidt 2010), and treatments with several antifungal compounds were tested. Treatment at the tadpole stage may reduce the incidence of disease in later stages of host development. These experiments test a broad range of potential treatment protocols across a variety of life stages and contexts important for mitigating the emerging amphibian disease chytridiomycosis.

\section{MATERIALS AND METHODS}

\section{Treating newly metamorphosed Bufo bufo with antimicrobial peptides}

\section{Animal husbandry}

Four amplexing pairs of common toads Bubo bufo were collected at the pond on the Färberwiesli, near Schaffhausen, Switzerland $\left(47^{\circ} 42^{\prime} 1.19^{\prime \prime} \mathrm{N}\right.$, $8^{\circ} 35^{\prime} 42.45^{\prime \prime}$ E) in March 2010, and kept in captivity overnight for egg collection. Tadpoles were reared in outdoor artificial ponds $\left(0.28 \mathrm{~m}^{2}\right.$ plastic tubs containing 801 of water) at the University of Zurich. Artificial ponds were disinfected before use with Virkon S (DuPont), covered with shade cloth, provided with leaves and zooplankton to establish semi-natural conditions, and irregularly supplemented with fish feed (Sera Spirulina Tabs; Sera GmbH). Upon metamorphosis, toadlets were transferred to tubs with access to land and water and fed crickets, aphids, and fruit flies. Temperature in the tubs fluctuated naturally and reached $30^{\circ} \mathrm{C}$ on several occasions. On July 12, 2010, 75 B. bufo metamorphs (mean \pm SD: $0.094 \pm 0.029 \mathrm{~g}$ ) were placed in a controlled environment room kept between 17 and $18.5^{\circ} \mathrm{C}$ on a $14 \mathrm{~h}$ light:10 h dark schedule with full-spectrum lighting. Each toadlet was given a new plastic enclosure tipped to one side containing approximately $25 \mathrm{ml}$ of aged tap water, and fed crickets 2 to 3 times weekly during the laboratory experiment. Relative humidity 
was consistently $100 \%$ in both outdoor tubs and laboratory enclosures. Temperature and humidity were recorded with LogTag Recorders. Under these husbandry conditions, the toads were considered to be free of $B d$ infections at the beginning of treatments.

\section{Experimental design}

The toadlets were randomly allocated to 1 of 5 treatment regimes and placed in a randomized block design. Initial mass did not significantly differ among treatments (ANOVA: $F=0.907, \mathrm{df}=4, \mathrm{p}=0.465$ ). Toadlets were exposed 1 time to either $B d\left(7 \times 10^{5}\right.$ zoospores mixed from UK Bufo bufo isolate and Swiss Alytes obstetricans isolate 0739) or a sham solution of water washed from sterile plates by placing in a sterile $15 \mathrm{ml}$ tube with $1 \mathrm{ml}$ solution for $1 \mathrm{~h}$. Peptides were rinsed from Pelophylax esculentus skin after norepinephrine induction (40 nmol g $\mathrm{n}^{-1}$ body mass) of granular gland secretions. Peptide treatment consisted of a 2 min bath in $1 \mathrm{ml}$ solution containing $400 \mu \mathrm{g} \mathrm{ml}^{-1}$ peptide mixtures collected from 15 P. esculentus and partially purified over C-18 Sep-Paks (Waters Corp.) and combined. This peptide concentration was approximately the minimal concentration needed to completely inhibit growth of $B d$ (D.C. Woodhams unpubl. data). In Treatment 1, toadlets $(n=12)$ were unexposed controls. In Treatment 2 toadlets $(\mathrm{n}=12)$ were not exposed to $B d$ but treated with peptides. In Treatment 3 toadlets $(n=17)$ were exposed to $B d$. In Treatment 4 toadlets $(\mathrm{n}=17)$ were exposed to $B d$ immediately after treatment with peptides. In Treatment 5 toadlets $(\mathrm{n}=17)$ were exposed to $B d$ and then treated with peptides on Days 8 and 9 after exposure. Toadlets were monitored daily for clinical signs of disease and weighed 2 and $5 \mathrm{wk}$ after exposure. At the end of the experiment on Day 35, the skin of toadlets was swabbed for quantitative real time PCR ( $\mathrm{PPCR}$ ) diagnostic analysis of $B d$ infection according to Hyatt et al. (2007). Standard statistical analyses were carried out using IBM SPSS Statistics 19 (SPSS Inc.) for this and the following experiments.

\section{Treating adult Rana muscosa with itraconazole and biotherapy}

\section{Animal husbandry}

Forty-four adult Rana muscosa (mean \pm SD: $8.8 \pm$ $2.1 \mathrm{~g})$ were collected from Sixty Lake Basin in the Sierra Nevada mountains of California, USA, trans- ported by helicopter out of the park in individual plastic containers, and shipped overnight to James Madison University, Harrisonburg, Virginia, USA, arriving on July 13, 2007. These lakes were known to be heavily infected with $B d$ and were thought to be in imminent danger of population collapse caused by chytridiomycosis. One frog was moribund upon collection in the field and died $2 \mathrm{~d}$ after arrival. Upon arrival at the laboratory, each frog was swabbed on the left side only for qPCR diagnostic analysis of $B d$, as above. Each frog was then rinsed in sterile artificial pond water (Provisoli medium, Wyngaard \& Chinnappa 1982) to remove debris and transient microbes, and swabbed on the right side for analysis of skin microbiota by denaturing gradient gel electrophoresis (DGGE, described in 'DGGE'). Next the frogs were weighed, treated, and placed individually into 21 plastic containers containing a $5 \mathrm{~cm}$ plastic saucer and approximately $200 \mathrm{ml}$ of artificial pond water. All containers were randomly assigned a position on metal racks in a controlled environment room set at $17^{\circ} \mathrm{C}$ with a $12 \mathrm{~h}$ light:12 h dark cycle. Containers were cleaned with $10 \%$ bleach and autoclaved twice per week. Artificial pond water was autoclaved and cooled before use. Frogs were fed crickets twice per week.

\section{Experimental design}

Frogs were randomly allocated to 3 treatments: control $(\mathrm{n}=13)$, biotherapy $(\mathrm{n}=20)$, and itraconazole $(\mathrm{n}=$ 10). Analysis of variance showed no significant differences among treatments in initial mass (mean $\pm \mathrm{SD}$ : $8.8 \pm 2.1 \mathrm{~g}, F=0.72, \mathrm{df}=2, \mathrm{p}=0.493$ ) or $B d$ load (mean $\pm \mathrm{SD}: 46888 \pm 92716$ zoospore equivalents, $F=0.371$, $\mathrm{df}=2, \mathrm{p}=0.692$ ). Four days after arrival, control frogs were treated by placing them in $25 \mathrm{ml}$ of artificial pond water for $2 \mathrm{~h}$ and 'swishing' every $30 \mathrm{~min}$. Biotherapy frogs were treated similarly, except that the water contained Pedobacter cryoconitis at a concentration of approximately $1.57 \times 10^{8}$ cells $\mathrm{ml}^{-1}$. The $P$. cryoconitis strain used was originally isolated from a wild adult Rana muscosa from Sixty Lake Basin in August, 2005, and found to inhibit $B d$ growth in co-culture assays (Woodhams et al. 2007). A pure culture was incubated for $24 \mathrm{~h}$ at room temperature in $1 \%$ tryptone with continuous stirring. The culture was then centrifuged at $4500 \mathrm{~g}$ for $10 \mathrm{~min}$ at $10^{\circ} \mathrm{C}$, and the supernatant was discarded. The cells were then washed by re-suspending the pellet in artificial pond water and repeating the centrifugation twice. A third group of frogs was treated for $11 \mathrm{~d}$ with itraconazole by placing each frog in a plastic container for $5 \mathrm{~min}$ with $25 \mathrm{ml}$ artificial 
pond water containing $250 \mu \mathrm{l}$ of Sporonox oral solution at $10 \mathrm{mg} \mathrm{ml}^{-1}$ (final concentration: $100 \mathrm{mg} \mathrm{l}^{-1}$; Nichols et al. 2000). All frogs were weighed and swabbed for $B d$ each week, and microbiota swabs were taken 7 and $13 \mathrm{~d}$ after beginning the experiment.

Measuring skin $\mathrm{pH}$ and $B d$ infection

The dorsal and ventral skin pH of Rana muscosa ( $n=24$ ) was measured with a flat glass probe. The intensity of infection measured in zoospore equivalents was determined by quantitative PCR according to Boyle et al. (2004). Both of these measurements were repeated 7 times at weekly intervals. We tested for a difference between the dorsal and ventral skin $\mathrm{pH}$ at the initial timepoint with a paired $t$-test, and for an overall correlation between infection intensity and ventral or dorsal skin $\mathrm{pH}$ by Pearson correlation. Since these frogs were all initially infected in the wild, no comparisons between infected and uninfected skin $\mathrm{pH}$ or accurate analysis of skin $\mathrm{pH}$ through the time course of infection was possible.

\section{DGGE}

Bacterial DNA was extracted from skin swabs using Qiagen DNEasy Blood and Tissue kit (Qiagen) and amplified with bacterial specific 16S rRNA gene primers 357F and 907R (Muyzer \& Smalla 1998) designed to amplify the V4 and V5 regions of the $16 \mathrm{~S}$ rRNA gene. Amplicons from PCR were analyzed by DGGE with a Bio-Rad D-Code System (Bio-Rad Laboratories) on $8 \%(\mathrm{w} / \mathrm{v})$ polyacrylamide gels using gradients ranging from 30 to $60 \%$ (where $100 \%$ denaturant contains $7 \mathrm{M}$ urea and $40 \%$ formamide). Electrophoresis was carried out in $1 \times$ TAE $(40 \mathrm{mM}$ Tris, $20 \mathrm{mM}$ acetic acid, $1 \mathrm{mM}$ EDTA) buffer at $70 \mathrm{~V}$ for $18 \mathrm{~h}$ at $60^{\circ} \mathrm{C}$. Gels were stained with ethidium bromide (1:10 000 dilution) for $30 \mathrm{~min}$ and visualized on a UV transilluminator. Community profiles were aligned with pure isolates of Pedobacter cryoconitis for probable identification.

\section{Treating adult Lithobates pipiens with itraconazole and heat therapy}

$$
\text { Animal husbandry }
$$

Adult Lithobates pipiens were purchased from a commercial supplier (J. M. Hazen Frog Company) and kept in groups until initiating the experiment. Frogs were placed into individual plastic enclosures (approximately 21 ) with access to water and were fed with crickets 2 to 3 times weekly after water changes. All frogs were weighed and swabbed for $B d$ at the beginning of the experiment and again on Day 17 after treatments and then changed to clean housing. Natural infections ranged from 0 to 4330 zoospore equivalents before beginning treatments.

\section{Experimental design}

In February, 2007, 12 frogs were treated with itraconazole as above according to Nichols et al. (2000), except that daily treatments extended for only $5 \mathrm{~d}$. Frogs were rinsed and placed into a new container after each treatment. A second treatment consisted of 10 frogs given heat therapy. Individual plastic enclosures containing frogs were placed in an incubator at $30^{\circ} \mathrm{C}$ overnight, and then the temperature was raised to $35^{\circ} \mathrm{C}$ for $24 \mathrm{~h}$. The water was then changed, and frogs resumed feeding the next day. Control frogs were kept in larger plastic containers in groups of 3 and 4 individuals and kept at room temperature (about $23^{\circ} \mathrm{C}$ ) without special treatment.

\section{Treating newly metamorphosed Limnodynastes peronii with itraconazole}

Animal husbandry

Striped marsh frog Limnodynastes peronii larvae (n = 26) were collected from Tasmania's northwest coast, at sites where $B d$-infection status was unknown. Frog collections occurred in January and February 2009. Each animal was collected by hand using clean vinyl gloves, transferred to an individual plastic container $\left(200 \times 240 \times 330 \mathrm{~mm}^{3}\right)$ and transported to temperature $\left(18\right.$ to $\left.23^{\circ} \mathrm{C}\right)$ and light $(12 \mathrm{~h}$ light:12 h dark) controlled facilities at the Department of Primary Industries, Parks, Water and the Environment (DPIPWE), Newtown Laboratories in Hobart, Tasmania, Australia. These individuals were originally collected for an exposure experiment. However, $12 / 26(46 \%)$ of the newly metamorphosed L. peronii frogs died within $6 \mathrm{wk}$ of metamorphosis, before the experiment had begun. Clinical signs were consistent with other studies reporting mortality due to chytridiomycosis occurring shortly after metamorphosis (Rachowicz \& Vredenburg 2004, Garner et al. 2009a). Postmortem examinations on a subset of $L$. peronii 
metamorphs that died early determined that $4 / 5$ (80\%) of these individuals had $B d$ infections, one of which was confirmed with histopathology to be consistent with cases of severe chytridiomycosis (Berger et al. 1998, Pessier et al. 1999; see Fig. 4), and all had epidermal necrosis of an unknown etiology.

\section{Experimental design}

We assumed that all metamorphs were infected with $B d$; however, this could not be confirmed with PCR testing at the time. Metamorphs were monitored closely for clinical signs of chytridiomycosis. Two individuals displayed clinical signs of severe chytridiomycosis (loss of righting reflex, irregular skin sloughing and epidermal erythmia; see Fig. 4) and were therefore included in the treatment group. The remaining metamorphs $(\mathrm{n}=12)$ were randomly assigned to control and treatment groups. Froglets were placed in round $(5.5 \mathrm{~cm}$ diameter) clean plastic containers. Itraconazole (1\%: $10 \mathrm{mg} \mathrm{ml}^{-1}$ Sporonox oral solution; Symbion) was diluted to $0.1 \%$ in $0.6 \%$ saline solution for a final concentration of $100 \mathrm{mg} \mathrm{l}^{-1}$ (Nichols et al. 2000). Treated froglets were exposed to a bath of itraconazole solution $(10 \mathrm{ml})$ for $5 \mathrm{~min}$ for 3 consecutive days before treatment was discontinued because of high mortality. Control froglets were exposed to an identical solution with no itraconazole. At the end of the $5 \mathrm{~min}$ period, the metamorphs were rinsed with tap water and returned to their individual containers with fresh tap water.

\section{Treating larval Alytes obstetricans with commercial antifungals}

\section{Animal husbandry}

Tadpoles of Alytes obstetricans ( $\mathrm{n}=77$ ) were collected in November 2009 (33 of them in Itingen, Switzerland $\left(47^{\circ} 27^{\prime} 35.17^{\prime \prime} \mathrm{N}, 7^{\circ} 47^{\prime} 2.12^{\prime \prime} \mathrm{E}, 410 \mathrm{~m}\right.$ above sea level [masl]) and 44 in Zunzgen, Switzerland (47 $26^{\prime} 5.44^{\prime \prime} \mathrm{N}, 7^{\circ} 47^{\prime} 56.73^{\prime \prime} \mathrm{E}, 480 \mathrm{masl}$ ). For a separate experiment, $B d$-infected tadpoles were captured from Zunzgen, and 89 were raised through metamorphosis between summer 2010 and spring 2011. Tadpoles were reared in the laboratory in $0.28 \mathrm{~m}^{2}$ plastic containers containing $80 \mathrm{l}$ of tap water. The room was equipped with full-spectrum sunlight lamps on a $12 \mathrm{~h}$ photoperiod. Temperature was kept at 18 to $20^{\circ} \mathrm{C}$. Water was changed once a week, and tadpoles were fed ad libitum with fish feed (Sera Spir- ulina Tabs, Sera GmbH). From January 2010, tadpoles were kept individually in $1.5 \mathrm{l}$ plastic tubs using the same husbandry care. In the week before the experiment, we recorded the mass (Scaletec Instruments), the length from the snout to the beginning of the tail muscle, the developmental stage (Gosner 1960), and we swabbed the mouthpart of the tadpoles with a sterile rayon-tipped plain swab with a plastic applicator (Copan). We used separate latex gloves for handling each tadpole to avoid cross contamination. These measurements were repeated after the experiments. We analyzed the swabs for the presence of $B d$ using qPCR following the protocol by Boyle et al. (2004). We ran samples in duplicate and repeated the analysis when the 2 results were inconsistent. For statistical analyses, we used counts of genomic equivalents (zoospore counts) to compare effectiveness of agents. For each individual the experiment was finished after a week of treatment. After the experiment, all tadpoles were successfully treated for $7 \mathrm{~d}$ with itraconazole according to Garner et al. (2009a) and brought back to their original pond according to permit specifications. Additionally, 89 metamorphs were treated with itraconazole diluted to $0.01 \%$ aqueous solution (10 $\mathrm{mg} \mathrm{l}^{-1}$; Garner et al. 2009a, Tamukai et al. 2011) for 3 consecutive days before treatment was discontinued because of high mortality. The surviving frogs were returned near their pond of origin.

\section{Experimental design}

Tadpoles were randomly allocated to 3 treatments, each testing a different agent for efficiency against $B d$. One tested agent was PIP Pond Plus (Chrisal). PIP Pond Plus contains a mixture of undefined probiotic bacteria (Bacillus sp.), enzymes, and 0.5 to $2.4 \%$ isopropanol. However, the exact composition of the agent is a corporate secret of Chrisal. To be sure that we were not erroneously measuring the effect of isopropanol alone, we conducted a small pilot study in which an equivalent dosage of isopropanol was added. No effect of isopropanol on $B d$ loads or on tadpole condition was detected. The second agent tested was Steriplant N (Swiss Steriplant AG). Steriplant $\mathrm{N}$ is electrochemically activated water. It contains $99.96 \%$ water (drinking water quality) and $0.04 \%$ oxidants $\left(\mathrm{NaOCl}^{-}, \mathrm{ClO}_{2}, \mathrm{NaClO}_{3}, \mathrm{O}_{3}\right)$. Disinfection is thought to work through oxidation of microbes. The third tested agent was Mandipropamid (Syngenta Crop Protection AG). Mandipropamid was developed by the derivatization of phenylglycinamides and mandelamides (Lamberth et al. 2008). It 
was developed as an effective agent against oomycetes. Mandipropamid is soluble in water up to a concentration of $4.2 \mathrm{mg} \mathrm{l}^{-1}$.

(1) Efficiency test with PIP Pond Plus: infected tadpoles $(\mathrm{n}=28$ ) were assigned to 3 different treatment groups and a control group ( $\mathrm{n}=7$ in each group, housed individually). The agent was mixed into the water (1 l) daily over a period of $7 \mathrm{~d}$. Depending on the treatment group the following dosages were applied: $0 \mu \mathrm{l}$ (control, only stirring the water), 25, 50, and $100 \mu \mathrm{l}$. After $7 \mathrm{~d}$ the water was changed, and tadpoles were individually housed $7 \mathrm{~d}$ without treatment but with 2 water changes before swabbing them

(2) Efficiency test with Steriplan N: infected tadpoles ( $\mathrm{n}=28$ ) were assigned to 3 different treatment groups and a control group ( $\mathrm{n}=7$ in each group, housed individually). We mixed $5 \mathrm{ml}$ of the agent daily into the water $(5 \mathrm{ml}$ into $1 \mathrm{l}=5 \mathrm{ppm}$ daily). Depending on the treatment group this treatment was applied $0 \mathrm{~d}$ (control, $0 \mathrm{ppm}$ ), $1 \mathrm{~d}$ (5 ppm), $2 \mathrm{~d}$ (10 ppm), or $3 \mathrm{~d}$ (15 ppm). After $7 \mathrm{~d}$, the water was changed. Tadpoles were swabbed after 7 additional days of individual housing with 2 water changes.

(3) Efficiency test with mandipropamid: infected tadpoles $(n=21)$ were treated with different dosages of mandipropamid mixing different amounts of the agent into the water. The following dosages were tested: $0.01,0.02,0.04,0.06,0.08,0.1,0.15,0.2,0.4$, $0.6,0.8,1,1.2,1.4,1.6,1.8,2$, and $4 \mathrm{mg} \mathrm{l}^{-1}$, and 3 controls. As mandipropamid is hardly soluble in water, we dissolved it in acetone (300 $\mathrm{g} \mathrm{l}^{-1}$ ) before applying it to the water. Hence, we tested 4 tadpoles with different dosages of acetone that were equivalent to the $0.01,0.1,1$, and $4 \mathrm{mg}$ dosages (not shown in the figure). Standard statistical analyses were done using $\mathrm{R}$ 2.10.1 for all experiments.

\section{RESULTS}

\section{Treating newly metamorphosed Bufo bufo with antimicrobial peptides}

\section{Survival and infection status}

The rationale for this experiment was to determine whether bath exposure to amphibian antimicrobial peptides would significantly reduce the level of detectable $B d$ infection in a susceptible species. $B d$ exposure reduced survival compared to unexposed toadlets (Fig. 1A). Initial mass was a significant covariate with larger toadlets surviving longer (Cox regression, $\mathrm{p}<0.001$ ). Survival of toadlets in each treatment for the $35 \mathrm{~d}$ experiment was as follows. In Treatment 1 (unexposed controls), survival was 58.3\% (mean: $27.3 \mathrm{~d}$ ). In Treatment 2 (unexposed controls treated with peptides), survival was $63.6 \%$ (mean: $27.5 \mathrm{~d}$ ). In Treatment 3 (Bd-exposed controls), survival was $17.6 \%$ (mean:
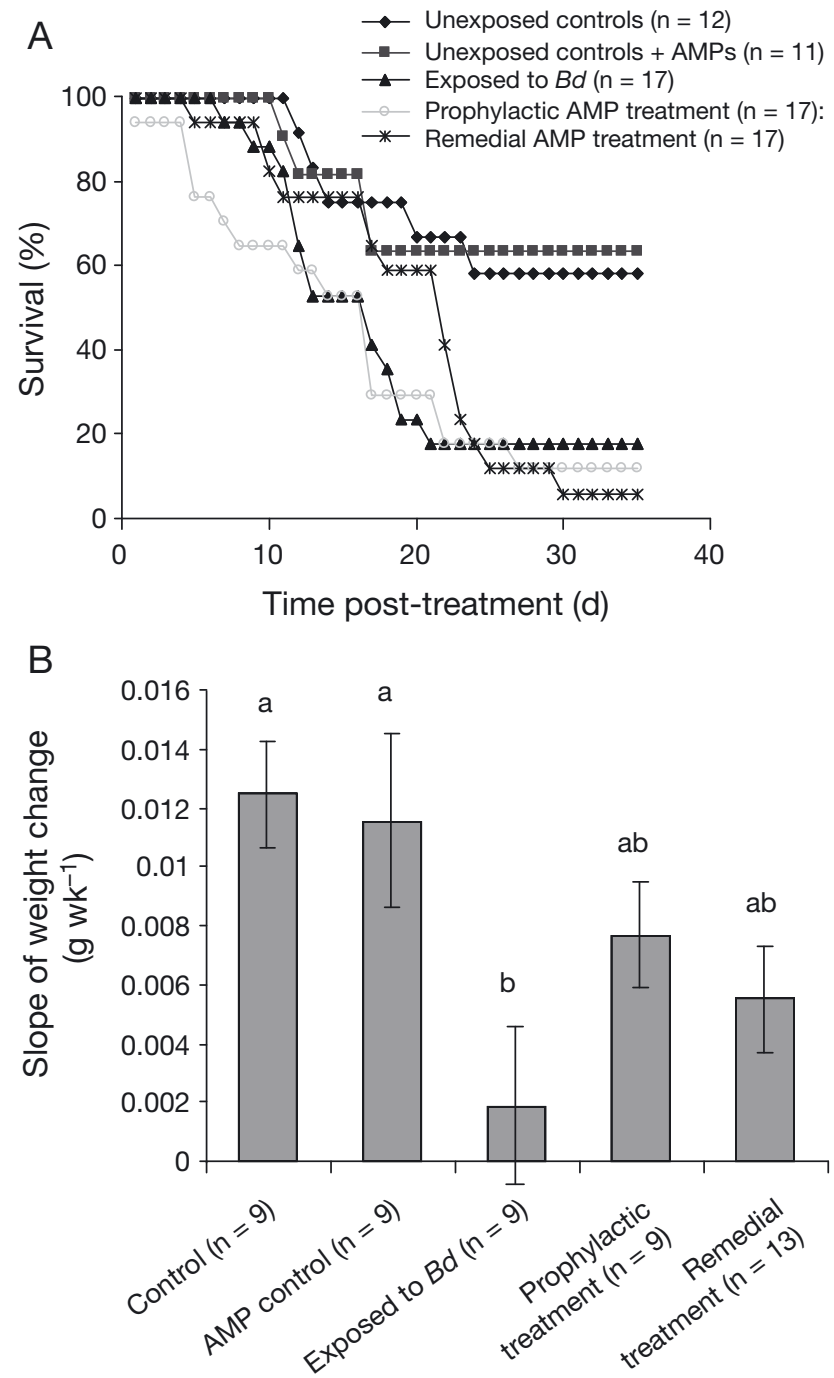

Fig. 1. Bufo bufo. Newly metamorphosed B. bufo treated with antimicrobial peptides (AMPs) either before exposure to Batrachochytrium dendrobatidis $(B d)$ or after experimental infection. Peptides were harvested non-destructively from the skin of the chytridiomycosis-resistant species Pelophylax esculentus (see 'Materials and methods'). (A) Kaplan-Meier survival curve of toads in each treatment throughout the experiment (log-rank test on censored survival data: $\chi^{2}=15.179$, df $=2, p=0.004$ ). (B) Mean $( \pm \mathrm{SE})$ change in weight throughout the experiment in all frogs weighed at least twice (ANOVA: $F=3.632, \mathrm{df}=4, \mathrm{p}=$ 0.012). Identical letters above bars indicate homogeneous subsets (Tukey test) 
17.9 d). In Treatment 4 (exposed after prophylactic treatment with antimicrobial peptides), survival was $11.8 \%$ (mean: $15.6 \mathrm{~d}$ ). In Treatment 5 (Bd exposed and treated with antimicrobial peptides 7 and $8 \mathrm{~d}$ after exposure), survival was $11.8 \%$ (mean: 20.9 d). Peptide treatment alone (Treatment 2) did not reduce survival compared to unexposed controls (Treatment 1); however, both groups experienced approximately $40 \%$ mortality, typical for the species (Garner et al. 2009b, Loman \& Madsen 2010). Neither prophylactic (Treatment 4) nor remedial peptide treatments (Treatment 5) improved survival compared to infected controls (Treatment 3). However, of the surviving toadlets, 3 of 3 exposed controls were $B d$ positive at the end of the experiment, and 0 of 3 exposed toadlets that were treated with peptides were infected by the end of the experiment, indicating a potential benefit of peptide treatments (Fisher's exact test, $\mathrm{p}=$ 0.05). Thus, although treatment with peptides did not improve survival, it may have prevented or induced the clearance of infection in a small number of individuals.

\section{Weight changes}

An analysis of variance of the rate of weight change throughout the experiment showed significant differences among treatments $(F=3.632, \mathrm{df}=4$, $\mathrm{p}=0.012$ ). Unexposed toadlets had the highest rate of growth, peptide-treated toadlets showed intermediate growth rate, and $B d$-exposed toadlets had the slowest rate of growth (Fig. 1B). Thus, treatment with Pelophylax esculentus peptides did not seem to negatively affect toad survival or growth; rather, peptide treatments before or after $B d$ exposure had similar beneficial effects on growth.

\section{Treating adult Rana muscosa with itraconazole or biotherapy}

\section{Survival}

$B d$ infection loads on adult Rana muscosa indicated relatively heavy infections in all frogs at the beginning of the experiment (Fig. 2). Thus, it was not possible to observe development of $B d$ infections in the frogs as in previous studies (Harris et al. 2009, Briggs et al. 2010), and mortalities began $3 \mathrm{~d}$ into the $51 \mathrm{~d}$ experiment. Survival of infected control frogs was $38.5 \%$ (mean: 31.5 d). Survival of frogs treated with Pedobacter cryoconitus was $50.0 \%$ (mean: 38.5 d). Survival of frogs treated with itraconazole was $30.0 \%$ (mean: 25.4 d). A log-rank


Fig. 2. Rana muscosa. Results of treating adult $R$. muscosa naturally infected with Batrachochytrium dendrobatidis $(B d)$ with the antifungal itraconazole or the probiotic bacterium Pedobacter cryoconitis. (A) Kaplan-Meier survival curve of frogs after treatments (log-rank test on censored survival data: $\chi^{2}=1.494, \mathrm{df}=2, \mathrm{p}=0.474$ ). (B) Intensity of infection with $B d$ throughout the experiment. (C) Mean $( \pm \mathrm{SE})$ change in weight throughout the experiment in all frogs weighed at least twice (ANOVA: $F=3.455$, df $=2, \mathrm{p}=$ 0.041 ). Identical letters below bars indicate homogeneous subsets (Tukey test) 
test on censored survival data did not demonstrate a significant difference among treatments $\left(\chi^{2}=1.494, \mathrm{df}=2\right.$, $\mathrm{p}=0.474 ;$ Fig. 2A). Controlling for initial frog mass and initial $B d$ load as covariates in a Cox regression did not show a significant effect of treatment $(p=0.381)$. All 17 frogs that died in either the infected control treatment or the biotherapy treatment were severely infected with $B d$ at death. Of the frogs that died in the itraconazole treatment, 2 of 7 were infected with $B d$ at death; thus, most frogs cleared infections before death. Three frogs survived the itraconazole treatment: $B d$ was initially undetectable from swabs on Day 60, but small zoospore loads were detected at a later time point, indicating incomplete clearance of $B d$ with itraconazole.
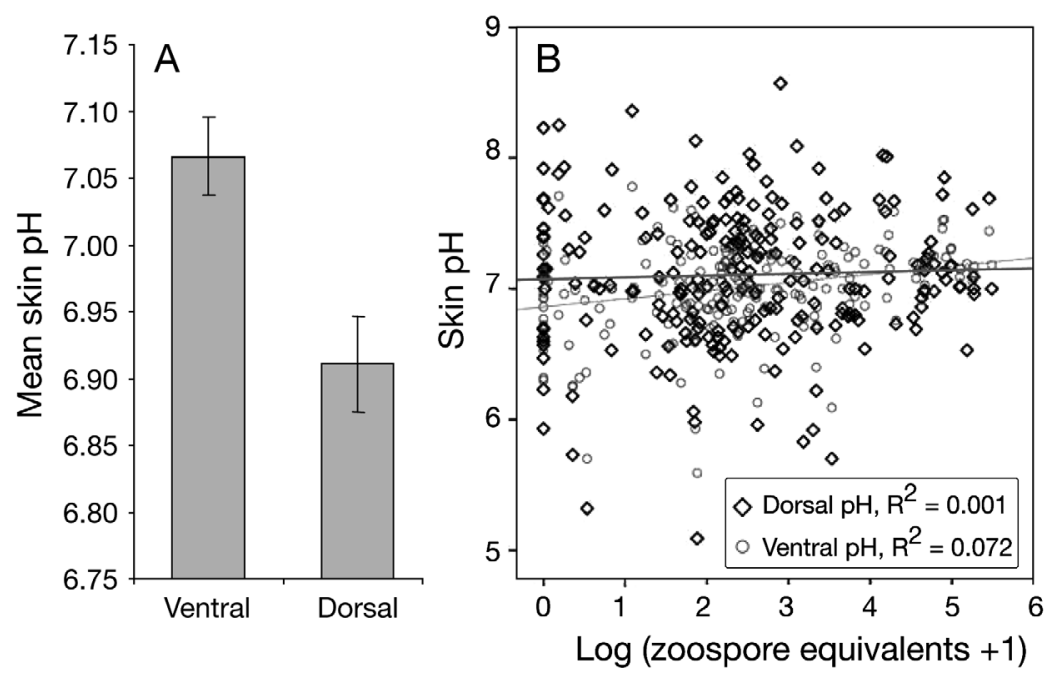

Fig. 3. Rana muscosa. Skin $\mathrm{pH}$ of $R$. muscosa infected with Batrachochytrium dendrobatidis $(B d)$. (A) Mean $( \pm \mathrm{SE}) \mathrm{pH}$ of ventral and dorsal skin surfaces. (B) Infection intensity shows a slight but significant correlation with ventral skin $\mathrm{pH}$ (light gray line) but not dorsal skin pH (dark gray line)

Weight changes

Frogs in all 3 treatment groups lost weight. Pedobacter cryoconitis treatment reduced weight loss due to $B d$ infection compared to infected controls, and itraconazole-treated frogs had intermediate weight loss (ANOVA: $F=3.455, \mathrm{df}=2, \mathrm{p}=0.041$; Fig. 2B). A general linear model did not indicate initial $B d$ load as a significant cofactor in weight loss $(\mathrm{p}>0.05)$.

\section{Bd and skin $\mathrm{pH}$}

Most frogs were heavily infected at the initiation of the experiment (Fig. 2B). Itraconazole quickly cleared $B d$ infections in surviving frogs, treatment with Pedobacter cryoconitis did not. Immediately after exposure to the bacterium (Day 2), zoospore loads were significantly reduced. At all later timepoints, infection intensity and prevalence were similar to values in infected controls (Fig. 2B). The skin $\mathrm{pH}$ of adult Rana muscosa naturally infected with $B d$ hovered around neutral (Fig. 3A), but the dorsal surface had a significantly lower $\mathrm{pH}$ than the ventral surface (paired $t$-test: $\mathrm{p}<0.0001$ ). Infection load was not significantly correlated with dorsal skin $\mathrm{pH}$ (Pearson's correlation: $\mathrm{p}=0.542$ ), but was weakly correlated with ventral skin $\mathrm{pH}$ (Pearson's correlation: $\mathrm{p}=0.0056$; Fig. 3B).

\section{DGGE}

Microbial community analysis showed that $63 \%$ of Rana muscosa were naturally colonized by Pedobacter cryoconitis at the initiation of the experiment, and this did not significantly differ among treatments (Pearson $\chi^{2}=0.084, \mathrm{df}=2, \mathrm{p}=0.959$ ). One group of 20 frogs was given a bath treatment in the bacterium. At $7 \mathrm{~d}$ after treatment, the bacterium had not become established on previously $P$. cryoconitis-negative frogs, and the bacterium was cleared from 1 of 12 initially P. cryoconitis-positive frogs. After $13 \mathrm{~d}, 1$ of 15 surviving frogs treated with $P$. cryoconitis retained the bacterium on its skin. This frog was not initially colonized. Of the surviving control frogs on Day 13 of the experiment, 0 of 9 showed P. cryoconitis colonization despite initial colonization on 6 of these frogs. Thus, this bacterium does not appear to be a good candidate for bioaugmentation because it does not persist after exposure of potential hosts.

\section{Treating adult Lithobates pipiens with heat therapy in comparison with itraconazole}

The short-term heat treatment was ineffective in clearing the infection in a small group of infected individuals, whereas itraconazole was effective in this experiment. Table 1 summarizes the results of diagnostic qPCR for each of the 3 treatments in comparison with untreated controls. Each treatment 
Table 1. Lithobates pipiens. Effects of itraconazole and elevated temperature on infection status of naturally infected adults. $B d$ : Batrachochytrium dendrobatidis

\begin{tabular}{|lccl|}
\hline Treatment & $\begin{array}{c}\text { No. of } \\
\text { frogs }\end{array}$ & $\begin{array}{c}\text { Initial infection } \\
\text { status }\end{array}$ & Treatment outcome \\
\hline Itraconazole & 4 & Bd positive & $4 / 4$ lost infections \\
$\left(100 \mathrm{mg} \mathrm{l}^{-1}\right)$ & 8 & $B d$ negative & $1 / 7$ became infected, 1 death \\
Heat & 4 & Bd positive & $4 / 4$ lost infections \\
$\left(35^{\circ} \mathrm{C}\right.$ for $\left.24 \mathrm{~h}\right)$ & 6 & Bd negative & $1 / 6$ became infected \\
Control & 4 & Bd positive & $0 / 4$ lost infections \\
$\left(23^{\circ} \mathrm{C}\right)$ & 3 & Bd negative & $3 / 3$ became infected \\
\hline
\end{tabular}

used in 3 different dosages with no significant effect on zoospore counts (Fig. 5B). Doses of mandipropamid between 0.01 and $4 \mathrm{mg} \mathrm{l}^{-1}$ did not significantly affect zoospore counts of infected A. obstetricans tadpoles (Fig. 5C). Infection prevalence effects are summarized in Table 2. We analyzed our data from the PIP Pond Plus treatment with different thresholds of zoospore equivalents to calculate infection prevalence (Fig. 5D). We analyzed the data with a factorial analysis of variance considering different thresholds factors and different treatments levels. We found that different thresholds (no threshold, 0.1 , and 1 zoospore equivalent) produced different results (from $100 \%$ infection prevalence without a threshold to $<60 \%$ infection prevalence at a threshold of 1 zoospore equivalent, $\mathrm{p}<0.001$; Fig. 5D).

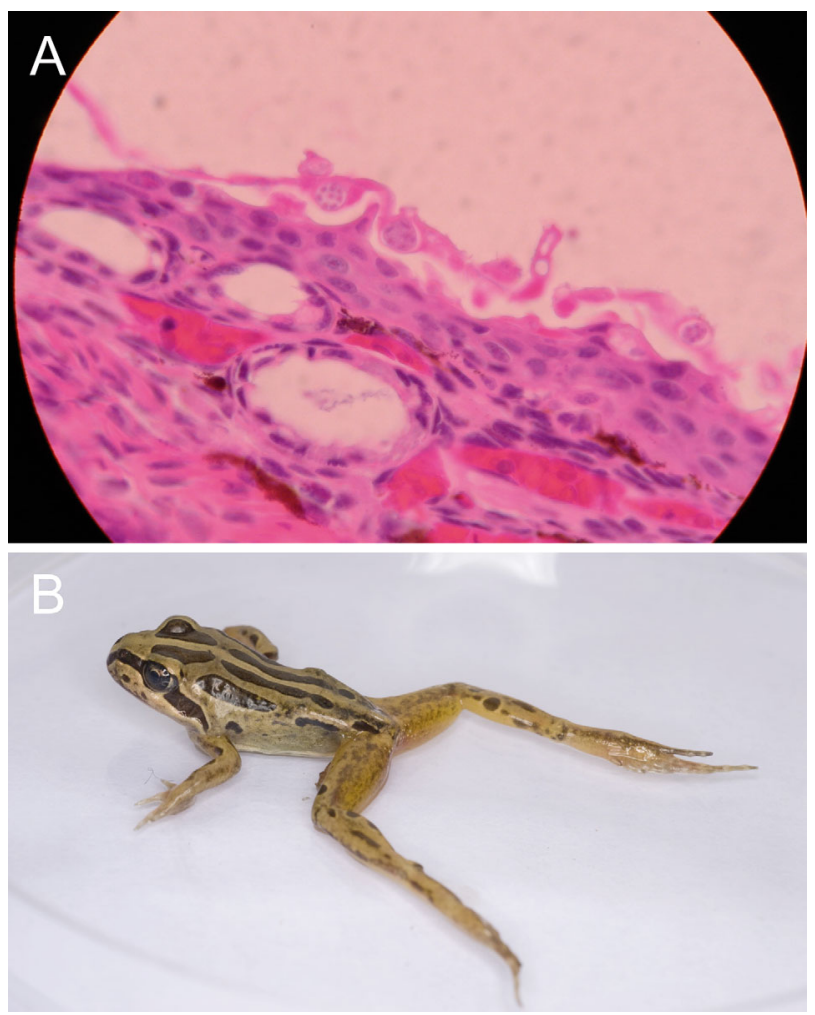

Fig. 4. Limnodynastes peronii. Striped march frogs that had naturally acquired infections with Batrachochytrium dendrobatidis $(B d)$ as tadpoles remained infected upon metamorphosis. (A) A histological section of the skin of an infected $L$. peronii stained with hematoxalin and eosin, showing clear hyperkeratosis of the epidermis and typical $B d$ zoosporangia. (B) A newly metamorphosed L. peronii with clinical signs of chytridiomycosis Electrochemically activated water (Steriplant N) was no significant effect on zoospore counts (Fig. 5A).

Three commercial antifungals were tested on $B d$ infected Alytes obstetricans tadpoles that had naturally acquired infections. There was no survival effect of any of the tested agents. The probiotic agent PIP Pond Plus was used in 3 different dosages with Electrochemically activated water (Steriplant $N$ ) was

group included some frogs that were infected initially and some that were uninfected. All frogs had previously been exposed to infected conspecifics. 4 infected frogs; however, 1 initially uninfected frog became $B d$ positive, and 1 frog died showing clinical signs of toxicity rather than acute chytridiomycosis. Heat therapy $\left(24 \mathrm{~h}\right.$ at $\left.35^{\circ} \mathrm{C}\right)$ did not help clear infections. All control frogs kept in group enclosures were The standard high-dose itraconazole treatment (100 $\mathrm{mg} \mathrm{l}^{-1}$ ) appeared to be highly toxic to these young metamorphs. Two froglets developed clinical after $2 \mathrm{~d}$ of itraconazole treatment. Clinical signs of chytridiomycosis were noted in 2 additional treatment, we discovered that an additional 4 treatment and 2 control froglets had died. Treatments were dissent to Lee Berger (James Cook University, Townsville, QLD, Australia) for isolation of $B d$.

\section{Treating larval Alytes obstetricans with commercial antifungals}



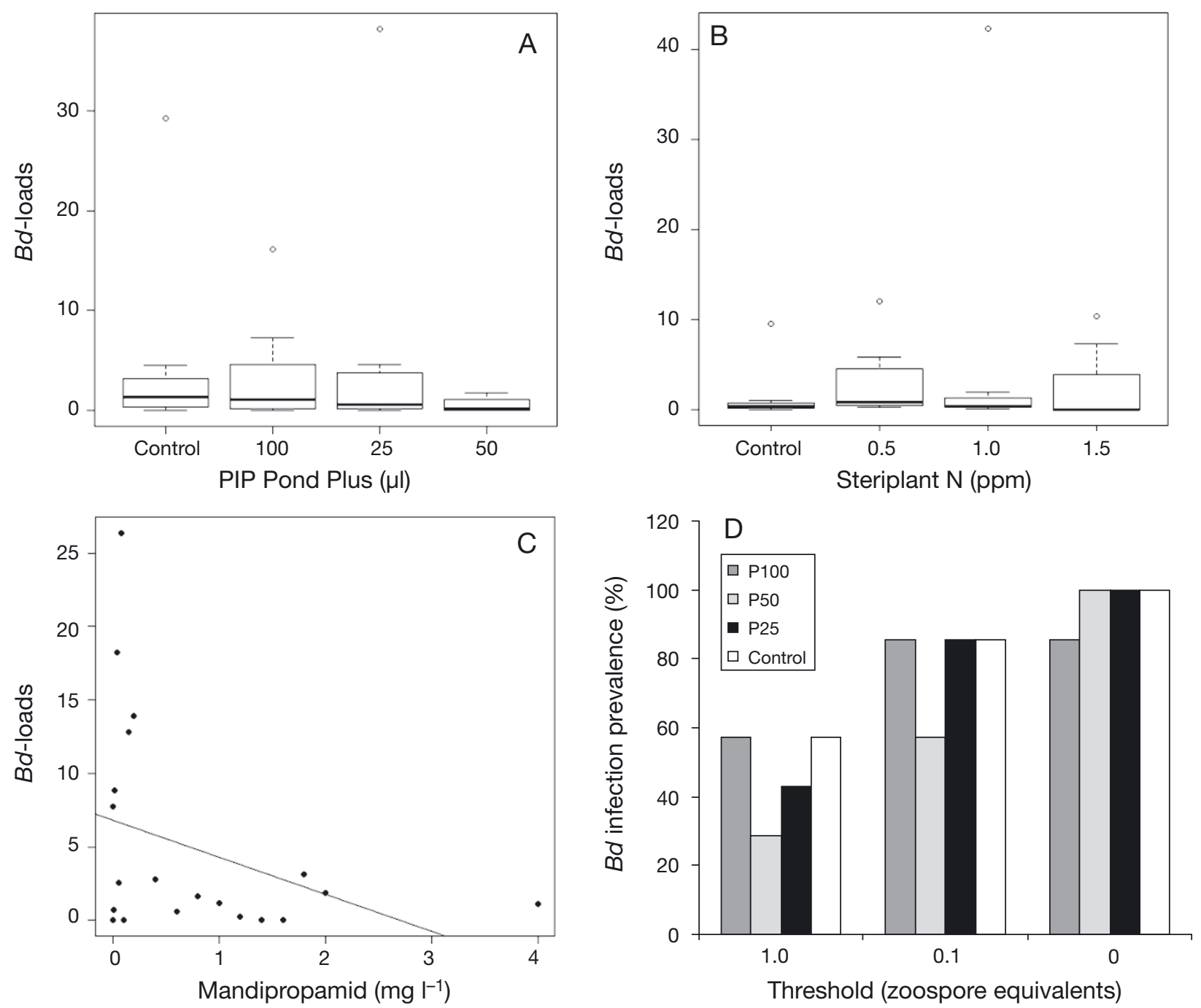

Fig. 5. Alytes obstericans. The effects of 3 commercial antifungal treatments applied to larval A. obstericans on Batrachochytrium dendrobatidis $(B d)$ infection intensities ( $B d \operatorname{load}=\log$ zoospore equivalents). (A) No significant effect of the PIP Pond Plus treatment on $B d$ load (ANOVA: $F=0.7148, \mathrm{df}=24, \mathrm{p}=0.5528$ ). (B) No significant effect of the Steriplant $\mathrm{N}$ treatment on $B d$ load (ANOVA: $F=0.3056, \mathrm{df}=24, \mathrm{p}=0.8210$ ). Box plots show the medium value (line), 25 and $75 \%$ quantiles (box), 5 and $95 \%$ quantiles (whiskers), and outliers (O). (C) No significant effect of the mandipropamid treatment on the Bd load (linear regression: $p=0.0638$ ). Five animals cleared infection, including 2 in the control group. The tadpole with the highest possible water-soluble dosage $\left(4 \mathrm{mg} \mathrm{l}^{-1}\right)$ was still infected with $B d$. (D) Thresholds of $B d$ zoospore intensity affect the interpretation of treatment results. All individuals with zoospore counts smaller than the threshold are considered uninfected. When no threshold is employed, almost all frogs regardless of treatment are considered infected. At higher thresholds, treatment seems to have a larger effect. Here, Treatments P100, P50, and P25 represent different dosages of the agent PIP Pond Plus (see 'Treating Alytes obstericans with commercial antifungals')

Juvenile Alytes obstetricans were raised from naturally $B d$-infected tadpoles in a separate experiment. They were never experimentally exposed to $B d$ in the laboratory. Collecting permits specified the return of these animals to the wild; thus, we began treatment with $0.01 \%$ itraconazole $\left(10 \mathrm{mg} \mathrm{l}^{-1}\right)$ before release. Although the dose of itraconazole was reduced from the standard adult treatment dose, 10, 5, and 2 individuals out of the 89 metamorphs died after the first, second, and third days of treatment, respectively, and then treatment with itraconazole was stopped.

\section{DISCUSSION}

Understanding the mechanisms by which chytridiomycosis can be suppressed is one of the first steps toward developing effective strategies to mitigate 
Table 2. Alytes obstetricans. Commercial antifungal treatments tested on infected tadpoles

\begin{tabular}{|c|c|}
\hline Treatment & Summary \\
\hline PIP Pond Plus & $\begin{array}{l}\text { Infected A. obstetricans tadpoles }(\mathrm{n}=28) \text { were treated with } 3 \text { different dosages of the probiotic agent } \\
\text { PIP Pond Plus. All individuals but } 1 \text { were still infected at low levels after the treatment. No significant } \\
\text { effect of the treatments on zoospore counts could be shown (Fig. 5A). }\end{array}$ \\
\hline Steriplant N & $\begin{array}{l}\text { Infected } A \text {. obstetricans tadpoles }(\mathrm{n}=28) \text { were treated with } 3 \text { different dosages of electrochemically } \\
\text { activated water (Steriplant } N) \text {. All individuals were still infected after the treatment. No significant } \\
\text { effect of the treatments on zoospore counts could be shown (Fig } 5 B) \text {. }\end{array}$ \\
\hline Mandipropamid & $\begin{array}{l}\text { Infected } A \text {. obstetricans tadpoles }(\mathrm{n}=21) \text { were treated with a range of dosages of mandipropamid. } \\
\text { Five animals were cured afterwards: the } 0.1,1.4 \text {, and } 1.6 \mathrm{mg} \mathrm{l}^{-1} \text { and } 2 \text { animals from the control group. } \\
\text { All other animals were still infected after the treatments. No significant effect of the treatment on } B d \\
\text { loads could be shown (Fig. } 5 \mathrm{C} \text { ). }\end{array}$ \\
\hline
\end{tabular}

chytridiomycosis. Manipulation of temperature regime, microbiota, and antifungal compounds including peptides are all strategies based on a growing ecological understanding of the disease chytridiomycosis (Woodhams et al. 2011). Although the results of experimental treatments presented here do not demonstrate significant survival benefits, they will be instrumental in the development of effective treatment protocols. To briefly summarize the lessons learned. (1) Low doses of itraconazole or alternatives should be tested in future treatments of adult frogs to avoid lethal side-effects, and treatment should be applied early, before damage from disease accrues. (2) Antimicrobial peptide applications may reduce or eliminate $B d$ infection in hosts such as Bufo bufo, a species that does not produce skin defense peptides. (3) A minimum elevated temperature regime should be developed for a range of species and life stages. For example, a treatment period of longer than $24 \mathrm{~h}$ at temperatures between 30 and $35^{\circ} \mathrm{C}$ appears to be necessary. (4) The probiotic Pedobacter cryoconitis had beneficial effects on heavily infected Rana muscosa; however, the effects were transient (Fig. 2) because this bacterium did not persist on the host skin. (5) A commercially available probiotic treatment (PIP Pond Plus) added to water at recommended and higher doses against fish disease did not improve survival of infected Alytes obstetricans tadpoles either (Table 2, Fig. 5). In vitro sensitivity tests against $B d$ may reduce animal use for experimental treatments that are not known to be antifungal a priori.

To date there are 2 published methods with apparent efficacy in clearing $B d$ infections in some species: antifungal drugs (itraconazole, voriconazole, terbinafine hydrochloride, and others) and temperature treatments (review in Berger et al. 2010, Bowerman et al. 2010, Martel et al. 2011, Woodhams et al. 2011). Itraconazole can be used to treat infected adults or larvae of some species; however, harmful side-effects including depigmentation of tadpoles have been noted (Garner et al. 2009a). We showed here that lethal side-effects occur when using the commonly applied itraconazole treatment regimes at high or reduced doses (Nichols et al. 2000, Garner et al. 2009a) on adult Rana muscosa, Alytes obstetricans, and Limnodynastes peronii. Thus, we suggest testing of lower doses on a range of species and life-history stages with controlled pharmacokinetic safety trials as outlined by Berger et al. (2010). To date, few studies have examined the dose-related effects of itraconazole.

Increasing evidence (review in Woodhams et al. 2011) indicates that elevated temperature can reduce the prevalence and intensity of $B d$ infections. Thus, elevated temperature may be used therapeutically for infected amphibians. However, the treatment regimes to minimize the temperatures and durations of treatment, in order to prevent unnecessary stress on the amphibians, has not been systematically tested. Our preliminary experiment with Lithobates pipiens adults was not a systematic test of heat treatment, but it did indicate that temperature treatments longer than $24 \mathrm{~h}$ may be needed to clear $B d$ infection. If the zoospore stage is primarily affected by temperature or other treatments, then treatment regimes should continue throughout the life cycle of the pathogen. A life cycle is about 4 to $5 \mathrm{~d}$ in laboratory culture, but could be longer in amphibian skin or at suboptimal temperatures. A $10 \mathrm{~d}$ treatment at $30^{\circ} \mathrm{C}$ was more successful in the clearance of $B d$ in Rana catesbeiana and Acris crepitans adults (Chatfield \& Richards-Zawacki 2011). A concern with the use of high temperature is that it may impair reproductive success. Examination of heat-treatment effects on egg and sperm quality should precede recommended protocols for elevated temperature. 
In addition to these more traditional treatments, we provide results from alternative treatments, such as the application of beneficial microbes or antimicrobial skin peptides. Recent studies have demonstrated that biotherapy can effectively prevent the establishment of $B d$ and increase survival of mountain yellowlegged frogs Rana muscosa (Harris et al. 2009). In our experiment, treated frogs initially limited $B d$ proliferation and slowed weight loss compared to $B d$-infected controls. DGGE microbial community analysis showed that although $63 \%(27 / 43)$ of $R$. muscosa were naturally colonized by Pedobacter cryoconitis, even after an additional bath treatment in the bacterium, only 1 of 15 frogs retained the bacterium on their skin $13 \mathrm{~d}$ post-treatment with individual housing in clean laboratory conditions. Although anti-Bd microbiota were previously shown to provide prophylactic benefits to $R$. muscosa and other amphibians (Harris et al. 2009, Becker \& Harris 2010), treatment of heavily infected frogs may require more frequent antifungal treatment or more persistent and strongly protective skin microbes. Probiotic treatments of human and veterinary diseases, as well as applications in agriculture and aquaculture, are often applied continuously or in pulses for the greatest benefit (Yang et al. 2001, Nikoskelainen et al. 2003, Frohmader et al. 2010, Magnadottir 2010, Thomas \& Greer 2010). Thus, a future research focus on prophylactic rather than remedial disease treatment may be warranted. Alternatively, more natural conditions, including housing frogs in groups in terrariums with soil may increase bacterial persistence. Since a reduction of microbial diversity may be a function of time in captivity, future trials should avoid this potential pitfall by using more natural conditions such as outdoor mesocosms.

Microbes compete for resources and may alter the micro-environment indirectly through triggering host immune defences or directly by oxygen and nutrient utilization, biofilm formation, or by production of antagonistic substances or altering skin $\mathrm{pH}$ (Wilson 2005). Here, we show that the $B d$ infection load was weakly correlated with ventral skin $\mathrm{pH}$ in Rana muscosa (Fig. 3). This could be the result of immunopathology. $B d$ prefers a $\mathrm{pH}$ of 6 to 7 , but growth is dramatically reduced at a of $\mathrm{pH} 4$ to 5 or pH 8 (Piotrowski et al. 2004). Secretion of cationic antimicrobial peptides may decrease the $\mathrm{pH}$ of the skin to create a hostile micro-environment. Lower $\mathrm{pH}$ on the dorsal surface, particularly during peptide discharge, may be a factor limiting infection there (Weldon \& Du Preez 2006, North \& Alford 2008, Sheafor et al. 2008). Here, higher $\mathrm{pH}$ on the ventral surface with higher $B d$ loads may be a cause or consequence of infection. Future studies on the effects of $\mathrm{pH}$ on skin infections may prove useful for disease management. We make the following recommendations:

(1) Develop additional animal models. The experiments with Bufo bufo illustrate the potential for this model system in understanding the role of antimicrobial skin defenses against $B d$. A recurring question is whether antimicrobial peptides on amphibian skin act as a protective mantle to resist infection, or as a first-aid kit to help deal with infection. Although we do not yet have a clear answer, ongoing studies suggest that some species are better protected than others by the constitutive release of antimicrobial peptides into the skin mucus. In our experiment, antimicrobial peptides may have prevented or eliminated $B d$ infection in 3 of 3 surviving toadlets that were exposed to $B d$. One drawback to experiments with $B$. bufo metamorphs is their typically low survival under seemingly benign laboratory and natural conditions (Garner et al. 2009b, Loman \& Madsen 2010).

(2) Attention to quality control of experimental protocols. Protocols to detect $B d$ infection in field surveys are often conservative to avoid false positives by using a qPCR detection threshold of 1 zoospore equivalent (Kriger et al. 2007, Vredenburg et al. 2010). In contrast, experimental treatments of $B d$-infected animals require protocols that are conservative to avoid false negatives. Thus, we do not recommend using a qPCR threshold infection intensity to diagnose infection. Rather, here, we compare zoospore equivalents among treatment and control groups to determine treatment effects on infection because estimates of infection prevalence can be misleading. Working with prevalence requires the arbitrary definition of a threshold of zoospore equivalents above which an animal is considered infected or below which an animal is considered uninfected. This can generate inaccuracies when a treatment reduces $B d$ loads strongly but does not completely clear Bd infection. After such a treatment many animals could have zoospore counts below the threshold and hence be considered uninfected. Yet these could be false negatives. Communicating these results in terms of prevalence might give a very promising impression of the treatment, but, in fact, all animals might still be infected at a low level. Our analysis of the PIP Pond Plus treatment with different zoospore equivalent thresholds illustrates this problem (Fig. 5D). A second recommendation, to reiterate Hyatt et al. (2007), is to swab treated animals at least twice after completion of the treatment, several weeks apart, to be sure that the infection was cleared. A third consideration is group size. 
Individual housing of amphibians may be important. In our preliminary experiment with Lithobates pipiens, transmission of $B d$ from infected to uninfected control frogs housed together emphasizes the importance of individual housing unless several groups are used with group as the level of replicate to avoid pseudo-replication. However, group housing may stabilize infection status (if microbial populations fluctuate on individuals and re-colonization can occur via transmission from group members) and be more indicative of disease dynamics in natural settings for some systems.

(3) Share information with a public database. We are currently developing a public database of amphibian disease treatments that will incorporate both published and unpublished accounts of such treatments. We welcome contributions and suggestions. One portion of the database will be dedicated to microbes detected on the skin of various amphibians, including the methods of identification and results of growth-inhibitory activity of the microbes or their metabolites. Such a database, in addition to the published literature on primarily successful disease treatments, will be valuable to inform future research and to alleviate the threat of chytridiomycosis.

Acknowledgements. We thank Tate Tunstall and Niklaus Peyer for assistance with qPCR, Leyla Davis for assistance with treating Alytes obstetricans metamorphs, and Beni Schmidt. This research was supported by the U.S. National Science Foundation Grant 0640373 to R.N.H. and 0619536 and 0843207 to L.A.R-S., the Swiss National Science Foundation 31-125099 to D.C.W., the Federal Office for the Environment (FOEN) the Swiss Cantonal Nature Conservation Offices, the World Association of Zoos and Aquariums (WAZA), the European Union Of Aquarium Curators (EUAC), the Institute of Evolutionary Biology and Environmental Studies and the Forschungskredit der Universität Zürich to C.C.G. Animal care and experimental procedures were approved by the Veterinary Authority for the canton of Zürich. Animal care and use committees at James Madison University and Vanderbilt University, and the State of Tasmania. Field collections were permitted by the Offices of Nature and Landscape for canton Schaffhausen, the 'Amt für Raumplanung' for the canton Basel-Landschaft, and the United States Department of the Interior National Park Service; they conformed to the 'Hygiene protocol for handling amphibians in field studies,' (www.jcu.edu.au/school/phtm/ PHTM/frogs/field-hygiene.pdf, 8 October, 2004).

\section{LITERATURE CITED}

Becker MH, Harris RN (2010) Cutaneous bacteria of the redback salamander prevent morbidity associated with a lethal disease. PLoS ONE 5:e10957

> Berger L, Speare R, Daszak P, Green DE and others (1998) Chytridiomycosis causes amphibian mortality associated with population declines in the rain forests of Australia and Central America. Proc Natl Acad Sci USA 95: 9031-9036

Berger L, Speare R, Marantelli G, Skerratt LF (2009) A zoospore inhibition technique to evaluate the activity of antifungal compounds against Batrachochytrium dendrobatidis and unsuccessful treatment of experimentally infected green tree frogs (Litoria caerulea) by fluconazole and benzalkonium chloride. Res Vet Sci 87:106-110

> Berger L, Speare R, Pessier A, Voyles J, Skerratt LF (2010) Treatment of chytridiomycosis requires urgent clinical trials. Dis Aquat Org 92:165-174

Bosch J, Rincón PA (2008) Chytridiomycosis-mediated expansion of Bufo bufo in a montane area of Central Spain: an indirect effect of the disease. Divers Distrib 14: $637-643$

Bosch J, Martinez-Solano I, Garcia-Paris M (2001) Evidence of a chytrid fungus infection involved in the decline of the common midwife toad (Alytes obstetricans) in protected areas of central Spain. Biol Conserv 97:331-337

Bowerman J, Rombough C, Weinstock SR, Padgett-Flohr GE (2010) Terbinafine hydrochloride in ethanol effectively clears Batrachochytrium dendrobatidis in amphibians. J Herp Med Surg 20:24-28

Boyle DG, Boyle DB, Olsen V, Morgan JAT, Hyatt AD (2004) Rapid quantitative detection of chytridiomycosis (Batrachochytrium dendrobatidis) in amphibian samples using real-time Taqman PCR assay. Dis Aquat Org 60:141-148

Briggs CJ, Knapp RA, Vredenburg VT (2010) Enzootic and epizootic of the chytrid fungal pathogen of amphibians. Proc Natl Acad Sci USA 107:9695-9700

> Chatfield MWH, Richards-Zawacki CL (2011) Elevated temperature as a treatment for Batrachochytrium dendrobatidis infection in captive frogs. Dis Aquat Org 94:235-238

> Daszak P, Cunningham AA, Hyatt AD (2000) Emerging infectious diseases of wildlife - threats to biodiversity and human health. Science 287:443-449

> Daszak P, Cunningham AA, Hyatt AD (2003) Infectious disease and amphibian population declines. Divers Distrib 9:141-150

Fisher MC, Bosch J, Yin Z, Stead DA and others (2009) Proteomic and phenotypic profiling of the amphibian pathogen Batrachochytrium dendrobatidis shows that genotype is linked to virulence. Mol Ecol 18:415-429

> Frohmader TJ, Chaboyer WP, Robertson IK, Gowardman J (2010) Decrease in frequency of liquid stool in enterally fed critically ill patients given the multispecies probiotic VSL\#3: a pilot trial. Am J Crit Care 19:e1-e11

Garner TWJ, Garcia G, Carroll B, Fisher MC (2009a) Using itraconazole to clear Batrachochytrium dendrobatidis infection, and subsequent depigmentation of Alytes muletensis tadpoles. Dis Aquat Org 83:257-260

> Garner TWJ, Walker S, Bosch J, Leech S, Rowcliffe JM, Cunningham AA, Fisher MC (2009b) Life history tradeoffs influence mortality associated with the amphibian pathogen Batrachochytrium dendrobatidis. Oikos 118: 783-791

> Garner TWJ, Rowcliffe JM, Fisher MC (2011) Climate change, chytridiomycosis or condition: an experimental test of amphibian survival. Glob Change Biol 17:667-675

Gascon C, Collins JP, Moore RD, Church DR, McKay JE, Mendelsson JR (2007) Amphibian conservation action plan. The World Conservation Union (IUCN), Gland

Geiger CC, Küpfer E, Schär S, Wolf S, Schmidt BR (2011) Elevated temperature clears chytrid fungus infections 
from tadpoles of the midwife toad, Alytes obstetricans. Amphib-Reptilia 32:276-280

Gosner KL (1960) A simplified table for staging anuran embryos and larvae with notes on identification. Herpetol J 16:183-190

Hadfield CA, Whitaker BR (2005) Amphibian emergency medicine and care. Sem Avian Exotic Pet Med 14:79-89

> Harris RN, Brucker RM, Walke JB, Becker MH and others (2009) Skin microbes on frogs prevent morbidity and mortality caused by a lethal skin fungus. ISME J 3:818-824

- Hoffmann M, Hilton-Taylor C, Angulo A, Böhm M, and others (2010) The impact of conservation on the status of the world's vertebrates. Science 330:1503-1509

Hyatt AD, Boyle DG, Olsen V, Boyle DB and others (2007) Diagnostic assays and sampling protocols for the detection of Batrachochytrium dendrobatidis. Dis Aquat Org 73:175-192

- Kriger KM, Ashton KJ, Hines HB, Hero JM (2007) On the biological relevance of a single Batrachochytrium dendrobatidis zoospore: a reply to Smith (2007). Dis Aquat Org 73:257-260

> Lamberth C, Jeanguenat A, Cederbaum F, De Mesmaeker A, Zeller M, Kempf HJ, Zeun R (2008) Multicomponent reactions in fungicide research: the discovery of mandipropamid. Bioorg Med Chem 16:1531-1545

Lips KR, Brem F, Brenes R, Reeve JD and others (2006) Emerging infectious disease and the loss of biodiversity in a neotropical amphibian community. Proc Natl Acad Sci USA 103:3165-3170

Loman J, Madsen TR (2010) Sex ratio of breeding common toads (Bufo bufo)-influence of survival and skipped breeding. Amphib-Reptilia 31:509-524

- Magnadottir B (2010) Immunological control of fish diseases. Mar Biotechnol (NY) 12:361-379

Marantelli G, Berger L, Speare R, Keegan L (2004) Distribution of the amphibian chytrid Batrachochytrium dendrobatidis and keratin during tadpole development. Pac Conserv Biol 10:173-179

Martel A, Van Rooij P, Vercauteren G, Baert K and others (2011) Developing a safe antifungal treatment protocol to eliminate Batrachochytrium dendrobatidis from amphibians. Med Mycol 49:143-149

Mendelson JR, Lips KR, Gagliardo RW, Rabb GB and others (2006) Biodiversity - confronting amphibian declines and extinctions. Science 313:48

> Muyzer G, Smalla K (1998) Application of denaturing gradient gel electrophoresis (DGGE) and temperature gradient gel electrophoresis (TGGE) in microbial ecology. Antonie van Leeuwenhoek 73:127-141

Nichols DK, Lamirande EW, Pessier AP, Longcore JE (2000) Experimental transmission and treatment of cutaneous chytridiomycosis in poison dart frogs (Dendrobates auratus and Dendrobates tinctorius). In: Proceedings of the American Zoo Veterinarians and International Association for Aquatic Animal Medicine Joint Conference, New Orleans, LA, 17-21 September 2000, p 42-44

Nikoskelainen S, Ouwehand AC, Bylund G, Salminen S, Lilius EM (2003) Immune enhancement in rainbow trout (Oncorhynchus mykiss) by potential probiotic bacteria (Lactobacillus rhamnosus). Fish Shellfish Immunol 15: 443-452

North S, Alford RA (2008) Infection intensity and sampling locality affect Batrachochytrium dendrobatidis distribution among body regions on green-eyed tree frogs Litoria genimaculata. Dis Aquat Org 81:177-188
Parker JM, Mikaelian I, Hahn N, Diggs HE (2002) Clinical diagnosis and treatment of epidermal chytridiomycosis in African clawed frogs (Xenopus tropicalis). Comp Med 52:265-268

Pessier AP, Mendelson JR (eds) (2010) A manual for control of infectious diseases in amphibian survival assurance colonies and reintroduction programs. IUCN/SSC Conservation Breeding Specialist Group, Apple Valley, MN

> Pessier AP, Nichols DK, Longcore JE, Fuller MS (1999) Cutaneous chytridiomycosis in poison dart frogs (Dendrobates spp.) and White's tree frogs (Litoria caerulea). J Vet Diagn Invest 11:194-199

> Piotrowski JS, Annis SL, Longcore JF (2004) Physiology of Batrachochytrium dendrobatidis, a chytrid pathogen of amphibians. Mycologia 96:9-15

Pounds JA, Bustamante MR, Coloma LA, Consuegra JA and others (2006) Widespread amphibian extinctions from epidemic disease driven by global warming. Nature 439: 161-167

> Rachowicz LJ, Vredenburg VT (2004) Transmission of Batrachochytrium dendrobatidis within and between amphibian life stages. Dis Aquat Org 61:75-83

Roseghini M, Erspamer GF, Severini C, Simmaco M (1989) Biogenic amines and active peptides in extracts of the skin of thirty-two European amphibian species. Comp Biochem Physiol 94C:455-460

Sheafor B, Davidson EW, Parr L, Rollins-Smith L (2008) Antimicrobial peptide defenses in the salamander, Ambystoma tigrinum, against emerging amphibian pathogens. J Wildl Dis 44:226-236

Skerratt LF, Berger L, Speare R, Cashins S and others (2007) Spread of chytridiomycosis has caused the rapid global decline and extinction of frogs. EcoHealth 4:125-134

Smith KG, Lips KR, Chase JM (2009) Selecting for extinction: nonrandom disease associated extinction homogenizes amphibian biotas. Ecol Lett 12:1069-1078

Stuart SN, Chanson JS, Cox NA, Young BE and others (2004) Status and trends of amphibian declines and extinctions worldwide. Science 306:1783-1786

Tamukai K, Une Y, Tominaga A, Suzuki K, Goka K (2011) Treatment of spontaneous chytridiomycosis in captive amphibians using itraconazole. J Vet Med Sci 73: 155-159

Thomas DW, Greer FR (2010) Probiotics and prebiotics in pediatrics. Pediatrics 126:1217-1231

Tobler U, Schmidt BR (2010) Within- and among-population variation in chytridiomycosis-induced mortality in the toad Alytes obstetricans. PLoS ONE 5:e10927

Vredenburg VT, Knapp RA, Tunstall TS, Briggs CJ (2010) Dynamics of an emerging disease drive large-scale amphibian population extinctions. Proc Natl Acad Sci USA 107:9689-9694

> Weldon C, Du Preez LH (2006) Quantitative measurement of Batrachochytrium dendrobatidis in amphibian skin. Dis Aquat Org 72:153-161

> Whiles MR, Lips KR, Pringle C, Kilham SS, and others (2006) The consequences of amphibian population declines to the structure and function of neotropical stream ecosystems. Front Ecol Environ 4:27-34

White AW (2006) A trial using salt to protect green and golden bell frogs from chytrid infection. Herpetofauna 36:93-96

Wilson M (2005) Microbial inhabitants of humans: their ecology and role in health and disease. Cambridge University Press, Cambridge 
Woodhams DC, Alford RA, Marantelli G (2003) Emerging disease of amphibians cured by elevated body temperature. Dis Aquat Org 55:65-67

Woodhams DC, Rollins-Smith LA, Briggs CJ, Vredenburg VT and others (2007) Symbiotic bacteria contribute to innate immune defenses of the threatened mountain yellow-legged frog, Rana muscosa. Biol Conserv 138: 390-398

Woodhams DC, Hyatt AD, Boyle DG, Rollins-Smith LA (2008) The northern leopard frog Rana pipiens is a widespread reservoir species harboring Batrachochytrium dendrobatidis in North America. Herpetologica 39:66-68

Editorial responsibility: Alex Hyatt, Geelong, Victoria, Australia
Woodhams DC, Bosch J, Briggs CJ, Cashins S and others (2011) Mitigating amphibian disease: strategies to maintain wild populations and control chytridiomycosis. Front Zool 2011 8:8

Wyngaard GA, Chinnappa CC (1982) General biology and cytology of cyclopoids. In: Harrison FW, Cowden RR (eds) Developmental biology of freshwater invertebrates. AR Liss, New York, NY, p 485-533

Yang C, Crowley DE, Menge JA (2001) 16S rDNA fingerprinting of rhizosphere bacterial communities associated with healthy and Phytophthora infected avocado roots. FEMS Microbiol Ecol 35:129-136

Submitted: August 3, 2011; Accepted: November 25, 2011 Proofs received from author(s): February 6, 2012 